\title{
EDITORIAL:
}

\section{Covid-19 dan Kekerasan Terhadap Perempuan Sebagai Pandemi Bayangan (The Shadow Pandemic)}

Sampai saat ini, setiap orang di seluruh dunia masih berbicara tentang pandemi Covid-19 dan kesulitan ekonomi global. Apa yang tidak atau jarang didiskusikan banyak orang adalah pandemi jahat lainnya yang membayangi yaitu: peningkatan kekerasan terhadap perempuan (KTP) atau violence against women (VAW). Di tengah kombinasi dari sistem kesehatan yang kewalahan, karantina wilayah yang diberlakukan secara ketat, ketakutan akan virus dan efek vaksinasi, dan ketidakpastian ekonomi, di saat itu pula KTP telah menemukan peluang kotor untuk berkembang bersamaan dengan meluasnya pandemi Covid-19. Perserikatan Bangsa-Bangsa (PBB) menyebut fenomena KTP pada masa pendemi ini sebagai "the shadow pandemic" (pandemi bayangan) (United Nations, 2020). Upaya penghapusan KTP sebagai pandemi bayangan oleh PBB bersama dengan negara-negara anggota di seluruh dunia menemui masa krisisnya selama pandemi Covid19 masih mendominasi dunia.

Mendefinisikan KTP secara khusus di antara kekerasan lain terhadap manusia pada umumnya, dan upaya mendapatkan perhatian dan pengakuannya secara global dan lokal bagi pencegahan dan kesudahannya, memerlukan perjuangan tersendiri. Yang membedakan KTP secara eksklusif adalah targetnya perempuan (dewasa atau anak) semata karena jenis kelamin dan gender mereka. KTP pun sering disebut sebagai 
kekerasan berbasis gender (KBG) atau gender-based violence (GBV) dan kekerasan berbasis gender dan seksual (KBGS) atau sexual and gender-based violence (SGBV). KBG dan KGBS, di sini sebagai jenis KTP, seringkali dipandang sebagai mekanisme penaklukan terhadap kaum perempuan yang terjadi baik dalam masyarakat secara umum maupun dalam hubungan interpersonal. Penaklukan ini dapat timbul dari rasa berhak, superioritas, dan misogini (kebencian terhadap perempuan) yang merupakan manifestasi dari hubungan kekuasaan dan ketidaksetaraan yang secara historis dan struktural tidak setara antara perempuan dan laki-laki, yang pada umumnya berlaku di semua wilayah dunia. Superioritas maskulinitas yang dijunjung tinggi martabatnya ketimbang femininitas oleh patriarkhi telah ‘menormalkan' dan 'mengalamiahkan' lelaki dan negara maskulin sebagai pelaku utama pada umumnya dari segala bentuk KTP.

KTP dapat terjadi di ranah privat atau domestik, di ranah publik dan ruang maya yang mengandung unsur kekerasan fisikal, psikologis, seksual dan finansial atau ekonomi pada setiap jenis dan bentuk KTP. Pelakunya adalah individu, kelompok secara langsung dan negara secara tidak langsung bergender maskulin.

KTP di ranah privat berjenis KBG/KBGS terjadi di dalam rumah tangga. Bentuknya adalah kekerasan dalam rumah tangga (KDRT) dan juga kekerasan pasangan intim (intimate partner violence/IPV). Biasanya terjadi antarindividu yang berhubungan melalui keintiman, ikatan darah atau hukum. Dalam KDRT dan IPV mengandung unsurunsur kekerasannya, yaitu kekerasan fisikal, seperti: menampar, memukul dengan tinju, menendang bagian tubuh, menusuk dengan pisau, dan lainnya. Unsur kekerasan psikologis seperti: intimidasi, pelecehan, penguntitan, perusakan properti, pelecehan verbal, ejekan atau penghinaan di depan umum, perselingkuhan dalam perkawinan, dan lainnya. Unsur kekerasan seksual, seperti pemerkosaan, pelecehan seksual, tindakan mesum, menyerang bagian seksual tubuh korban. Sedangkan unsur kekerasan ekonomi adalah penyalahgunaan keuangan atau ekonomi termasuk secara paksa mengendalikan uang atau aset orang lain, pencurian uang tunai, tidak mengizinkan korban untuk mengambil bagian dalam keputusan keuangan apa pun, atau mencegah korban memiliki pekerjaan (WHO, n.d.)

KTP di ruang publik atau masyarakat berjenis KBG/KBGS terjadi di luar rumah tangga, yaitu pada ragam fasilitas umum, seperti kantor, sekolah, jalan, kendaraan umum dan di tempat lainnya. Bentuknya adalah kekerasan dalam ruang publik (KDRP) yang 
mengandung unsur-unsur kekerasannya. Biasanya dilakukan oleh orang lain yang memiliki jabatan/posisi lebih tinggi, majikan, atau orang lain/asing yang tak dikenal per individu atau kelompok. Kandungan unsur-unsur kekerasannya, yaitu unsur kekerasan fisikal, seperti mutilasi alat kelamin perempuan, sterilisasi paksa, hukuman fisik, perdagangan untuk industri seks dan industri jasa, pelacuran paksa, penganiayaan oleh majikan dan pembunuhan. Unsur kekerasan seksualnya seperti pemerkosaan, pelecehan seksual dan intimidasi seksual. Unsur kekerasan psikologisnya, seperti intimidasi, sanksi atau isolasi oleh norma-norma masyarakat/budaya yang didasarkan pada sikap diskriminasi gender. Sementara, unsur kekerasan ekonominya, yaitu pemotongan penghasilan, diskriminasi perolehan gaji, tidak ada akses bagi diskusi pengenai penghasilan dan pemerasan (WHO, n.d.).

KTP yang terjadi di ruang maya berjenis $\mathrm{KBG} / \mathrm{KBGS}$ adalah kekerasan yang difasilitasi oleh kemajuan teknologi berupa jaringan internet dan terdapat pada ragam platform media sosial. Pelakunya adalah pengguna (user) yang dikenal atau tak dikenal seperti netizen. Bentuk kekerasannya adalah pelecehan dan intimidasi seksual melalui penyebaran konten atau data privasi terkait dengan korban sebagai bentuk pemerasan (blackmailing); perundungan (bullying) dan mempermalukan dengan mempergunakan aspek tubuh atau seksualitas korban (body shaming); mengirim pesan (texting) atau komentar berbau seks; melakukan stalking yang membuat korban tidak nyaman.

Selain itu terdapat pula KTP dengan pelakunya adalah negara terdiri dari kekerasan politik, kekerasan custodian dan kekerasan institusional. Bentuk kekerasan politik, seperti toleransi kekerasan berbasis gender, perdagangan manusia, kehamilan paksa dan sterilisasi paksa. Kekerasan custodian, bentuknya seperti pemerkosaan militer dan polisi, penyiksaan, dan penindasan terhadap tindakan politik gerakan perempuan, pelecehan perempuan di kamp pengungsian dan relokasi, juga di penjara. Sementara, kekerasan institusional, seperti penegakan hukum dan peraturan yang diskriminatif, kebijakan dan program (kebijakan aborsi, kebijakan reproduksi) serta hukum matrilineal (Department of Health Republic of the Philippines, n.d.).

KTP merupakan permasalahan di seluruh dunia, terjadi pada tingkat yang lebih besar atau lebih kecil, di semua wilayah, negara, masyarakat dan budaya, yang memengaruhi perempuan tanpa memandang pendapatan, kelas, ras atau etnisnya. Menurut $U N$ Women satu dari tiga perempuan di seluruh dunia mengalami kekerasan fisik 
atau seksual, dan enam dari sepuluh perempuan secara sengaja dibunuh di seluruh dunia yang kebanyakan dilakukan oleh pasangan intim (lelaki), dan oleh lembaga atau negara. Lebih lanjut, KTP dapat mengakibatkan cedera atau penderitaan fisik, seksual atau psikologis jangka panjang bagi korban dan juga kematian. Dampak negatif dari KTP tidak hanya terhadap kehidupan pribadi para penyintas dan lingkungan terdekatnya tetapi juga terhadap perkembangan sosial dan ekonomi masyarakat, negara serta pencapaian tujuan pembangunan yang disepakati secara internasional. (UN Women, n.d.)

Dalam memerangi KTP ini, aktivisme feminis adalah pendorong perubahan perilaku dan kebijakan yang paling konsisten dan penting bagi nasib perempuan (McMillan, 2007). KTP telah menjadi perhatian utama bagi gerakan-gerakan perempuan dan feminis di negara-negara Barat (terutama Amerika Serikat dan Inggris) dan kemudian di negara-negara Timur. Gerakan feminis gelombang pertama yaitu feminisme arus utama (mainstream feminism), seperti feminisme liberal, reformist atau gender reform feminisms yang berkampanye di abad ke-19 telah menyadari keberadaan dan signifikansi KTP untuk disuarakan ke ruang publik. Mereka berpendapat bahwa incest dan pemukulan terhadap istri di ruang privat atau domestik adalah bagian dari pola umum kekerasan lakilaki seperti halnya tindakan pemerkosaan. Namun, pada pergantian abad, perhatian feminis ini beralih pada masalah hak pilih, hak politik dan properti, sehingga masalah KTP relatif tetap tersembunyi sampai munculnya feminisme gelombang kedua (McMillan, 2007).

Gerakan feminis gelombang kedua pada tahun 1960-an dan 1970-an dikenal sebagai gerakan feminisme radikal atau gender resistant feminisms membuat klaim bahwa 'pribadi adalah politik' (the personal is political) dan menuntut pemeriksaan ulang kehidupan sehari-hari perempuan. Terkait mengenai KTP, mereka menuntut bahwa KDRT tidak lagi dianggap sebagai sesuatu yang menjadi tanggung jawab perempuan, dan bahwa pemerkosaan dan kekerasan seksual tidak lagi dipandang sebagai kejahatan seks yang menyalahkan perempuan (McMillan, 2007). Sebaliknya, mereka menegaskan bahwa kekuasaan adalah isu sentral dalam KTP dan bahwa kekerasan seksual serta kekerasan domestik mencerminkan dan menentukan struktur sosial berbasis gender. Mereka juga menantang perbedaan antara publik dan privat/domestik, serta perilaku lembaga terhadap penyintas kekerasan seksual dan keengganan lembaga negara untuk campur tangan dalam situasi 'domestik'. Secara keseluruhan mereka menginginkan agar 
kekerasan didefinisikan ulang sebagai masalah kekuasaan yang melanggengkan ketidaksetaraan gender; mengakui sifat sistemik serta endemiknya dan berupaya untuk mengakhiri kekerasan ini (McMillan, 2007).

KTP, termasuk pemerkosaan, KDRT, dan pelecehan seksual, juga menjadi isu sentral gerakan feminis gelombang ketiga pada pertengahan 1990-an. Gerakan ini menganggap KTP sebagai "lapisan penindasan dan ketidaksetaraan" yang disebabkan tidak hanya karena jenis kelamin dan gendernya sebagai perempuan, tetapi juga ras, kelas dan bahkan agamanya (McMillan, 2007).

Pada 2012 feminisme gelombang keempat bangkit dengan komponen utama perjuangannya adalah penggunaan media internet dan ragam media sosial. Fokusnya pada pelecehan seksual, penghinaan terhadap tubuh, dan budaya pemerkosaan, di antara isuisu KTP lainnya, yang terdapat di dunia nyata maupun dunia maya dan permainan (virtual games).

Titik balik dari upaya terkait pencegahan dan penghapusan KTP yang telah disuarakan dan diadvokasi oleh gerakan-gerakan sosial perempuan dan para feminis di seluruh dunia ini adalah bermunculannya tanggapan serius dan pengakuan dari komunitas internasional dan pensahanya kemudian oleh institusi-institusi internasional. Sejumlah norma dan standar yang disepakati secara internasional terkait dengan mengakhiri KTP telah dihasilkan. Beberapa yang terpenting adalah Konvensi 1979 tentang Penghapusan Segala Bentuk Diskriminasi terhadap Perempuan (Convention on the Elimination of All Forms of Discriminations Against Women/CEDAW) yang mengakui kekerasan sebagai bagian dari diskriminasi terhadap perempuan dalam rekomendasi 12, 19 dan 35 . Selanjutnya selama tahun 1990-an, komunitas internasional mulai mengakui KTP sebagai hambatan hak asasi perempuan. Pada tahun 1992, CEDAW secara resmi mengakui bahwa KTP menghambat kesetaraan gender, meminta negara-negara anggota untuk melaporkan data yang relevan dan tindakan yang diambil untuk menangani masalah tersebut (CEDAW Committee, 1992).

Konferensi Dunia Hak Asasi Manusia 1993 mengakui KTP sebagai HAM, dan yang berkontribusi pada deklarasi PBB berikut ini (UN Women, n.d.) Deklarasi PBB 1993 tentang Penghapusan KTP adalah instrumen internasional pertama yang secara eksplisit mendefinisikan dan menangani kekerasan terhadap perempuan. Definisi ini telah diadopsi dalam Deklarasi Beijing dan Platform Aksi (Platform for Action) dan diterima 
dalam komunitas internasional. Konferensi Internasional Kependudukan dan Pembangunan tahun 1994 menarik hubungan antara kekerasan terhadap perempuan serta hak-hak dan kesehatan reproduktif. Platform Aksi Beijing 1995 mengidentifikasi tindakan khusus yang harus diambil pemerintah untuk mencegah dan menanggapi KTP. Mengakhiri kekerasan adalah salah satu dari 12 bidang tindakan prioritas (UN Women, n.d.)

Pada tahun 1996, World Health Organization (WHO) menyatakan kekerasan sebagai masalah kesehatan masyarakat yang utama. Salah satu dan subtipe kekerasan yang diakui adalah kekerasan pasangan intim dan kekerasan seksual sebagai KTP yang sering dilakukan. Pada tahun 1999, PBB mengadopsi Protokol Opsional untuk Konvensi Penghapusan Segala Bentuk Diskriminasi terhadap Perempuan dan menetapkan 25 November sebagai Hari Internasional untuk Penghapusan KTP (UN Women, n.d.). Pada tahun 2002, WHO menerbitkan Laporan Dunia Pertama tentang kekerasan dan kesehatan, yang membahas berbagai jenis kekerasan dan pengaruhnya terhadap kesehatan masyarakat, termasuk bentuk-bentuk kekerasan yang sangat memengaruhi perempuan. Pada tahun 2004, WHO menerbitkan "Studi Multinegara tentang Kesehatan Wanita dan KDRT terhadap Wanita", hasil dari mensurvei lebih dari 24.000 wanita di 10 negara dari seluruh wilayah dunia, yang menilai prevalensi dan tingkat kekerasan terhadap perempuan, terutama kekerasan oleh pasangan intim, dan mengaitkannya dengan hasil kesehatan bagi perempuan serta mendokumentasikan strategi dan layanan yang digunakan perempuan untuk mengatasi kekerasan pasangan intim (WHO, 2005).

Pada tahun 2006, Sekretaris Jenderal PBB menerbitkan dokumen internasional komprehensif pertama tentang semua bentuk KTP. Dewan HAM PBB pertama kali mengadopsi resolusi tentang percepatan upaya penghapusan segala bentuk kekerasan terhadap perempuan pada tahun 2012. Pada tahun 2020, pada sesi ke-64 Komisi Status Wanita, para pemimpin berjanji untuk meningkatkan upaya untuk sepenuhnya menerapkan Deklarasi dan Platform Aksi Beijing, termasuk mengakhiri semua bentuk kekerasan dan praktik berbahaya terhadap perempuan dan anak perempuan (UN Women, n.d.).

Upaya mengimplementasikan resolusi PBB tentang KTP pada tingkat global dilaksanakan oleh PBB sendiri melalui program-program Millennium Development Goals (MDGs) dan Sustainable Development Goals (SDGs.). Di antaranya, pada target 2 tujuan 
5 dari 17 SDGs adalah mencapai kesetaraan gender dan pemberdayaan perempuan untuk menghapuskan segala bentuk kekerasan terhadap semua perempuan dan anak perempuan di ruang publik dan privat, termasuk perdagangan manusia dan eksploitasi seksual dan jenis lain.

Beberapa upaya implementasi tingkat regional dan nasional juga telah dilaksanakan dalam mengadopsi Deklarasi Beijing tentang Penghapusan KTP. Pada tingkat regional, Konvensi Dewan Eropa 2011 tentang pencegahan dan pemberantasan KTP dan KDRT, yang merupakan instrumen regional kedua yang mengikat secara hukum tentang kekerasan terhadap perempuan dan anak perempuan. Negara-negara anggota Economic and Social Commission for Asia and the Pacific (ESCAP) menegaskan komitmen mereka terhadap Beijing Platform for Action dengan Asia-Pacific Declaration on Advancing Gender Equality dan Pemberdayaan Perempuan: Beijing +25 Review. Deklarasi ini sekali lagi menyerukan penghapusan KTP, menekankan KBGS terhadap perempuan di ruang publik dan privat merupakan hambatan utama pencapaian kesetaraan gender dan pemberdayaan perempuan. Sementara negara-negara ASEAN mendesak untuk memberikan prioritas pada penghapusan KTP dan berkomitmen untuk mengambil semua langkah yang tepat untuk mencegah dan menanggapi segala bentuk KTP di Asia Tenggara (ASEAN, n.d.).

Sementara pada tingkat nasional, setidaknya 155 negara telah mengesahkan undang-undang tentang kekerasan dalam rumah tangga, dan 140 negara memiliki undang-undang tentang pelecehan seksual di tempat kerja (UN Women, 2021). Di Indonesia telah ada lembaga tersendiri yang mengurusi mengenai KTP, yaitu Komisi Nasional Anti Kekerasan terhadap Perempuan.

Meskipun demikian, kemajuan untuk menghapus KTP tingkat global, regional dan nasional tidak stabil dan tidak merata di seluruh dunia. Bahkan dua puluh tahun setelah adopsi Deklarasi Beijing hanya ada sedikit perbaikan dalam penghapusan dan tingkat KTP. Tantangan tetap ada dalam menegakkan hukum dan dalam membuka akses bagi perempuan ke keselamatan dan keadilan. Terlebih lagi ketika pandemi Covid-19 melanda dunia yang mengancam kemampuan PBB dan negara-negara untuk menepati janji-janji semua deklarasi KTP.

Pandemi Covid-19 dimulai pada akhir tahun 2019 yang sampai kini tengah dihadapi oleh umat manusia di seluruh dunia. Selain efek pandemi Covid-19 
menimbulkan bencana-bencana kesehatan, ekonomi, sosial, dan lainnya, semua bencana itu juga mengandung dimensi gender dan seksualitas sebagai suatu bencana tersendiri. Bencana berdimensi gender dan seksualitas dalam struktur kekuasaan yang didominasi oleh kaum lelaki/patriarkhi menjadikan KTP, dengan perempuan yang menempati posisi paling rentan dalam struktur tersebut, sebagai manifestasi bencananya. Meskipun fenomena KTP bukan sesuatu yang baru dan telah ada di sepanjang sejarah manusia, namun pada masa pandemi Covid-19, KTP menunjukkan lonjakan yang luar biasa sebagai efek melekat dari pandemi Covid-19 yang kemudian dijuluki oleh PBB dan yang lainnya sebagai the shadow pandemic (pandemi bayangan).

KTP sebagai pendemi bayangan bukan disebabkan oleh jenis virus Corona baru, melainkan oleh penerapan protokol kesehatan yang dianjurkan oleh WHO kepada setiap negara sebagai langkah pencegahan dan mitigasi risiko bencana pandemi Covid-19 di tempat masing-masing. Protokol kesehatan berupa kebijakan-kebijakan seperti kebijakan isolasi atau karantina wilayah (lockdown), perintah untuk tetap dirumah (stay at home order), bekerja dari rumah (work from home/WFH), dan keharusan jaga jarak sosial (social distancing).

KTP sebagai pandemi bayangan terjadi secara meningkat disebabkan oleh penerapan protokol kesehatan di semua ruang (privat/domestik, publik dan maya) pada setiap jenis, bentuknya dan semua unsur kekerasan yang dikandungnya. Pelakunya adalah semua yang telah disebut sebelumnya.

Pandemi bayangan di ranah privat/ranah domestik berjenis KBG/KBGS terjadi di dalam rumah tangga dalam bentuk KDRT ketika penerapan kebijakan lockdown, stay at home order dan WFH menyasar para perempuan dengan tugas gender yang dibebankan kepadanya lebih besar dari pada sebelumnya. Perempuan tidak hanya mengemban tanggung jawab mengurus rumah tangga dan mengasuh anak tanpa asisten, tetapi juga ditugaskan sebagai guru bagi anak-anaknya dengan sistem pembelajaran daring selama pandemi. Bersamaan dengan itu, sebagai pendukung pencari nafkah ia juga perlu melakukan pekerjaannya dari rumah tanpa batas waktu dan insentif lembur, jaminan asuransi dan ketidakpastian pesangon. Dengan demikian perempuan mengemban multiganda peran, harus memikul banyak tanggung jawab dan beban yang sangat berat secara fisik, psikis dan ekonomi karena gender dan seksualitasnya bahkan melampaui gendernya. 
Pendemi bayangan di ranah privat/ranah domestik berikutnya adalah ketika penerapan isolasi, stay at home dan WFH justru meningkatkan intensitas pertemuan antarpasangan atau antarjenis kelamin di dalam rumah tanpa batas waktu dan halangan serta pengawasan sosial. Situasi seperti ini rawan terjadinya perbuatan asusila dan rentan terjadinya KDRT dan IPV. Perempuan karena jenis kelaminnya dianggap sebagai yang tak berdaya dan bersalah atas tubuhnya sendiri sehingga pantas menerima siksaan fisik, psikis dan seksual. Lebih dari itu, seorang suami kerap merasa perlu untuk melakukan kekerasan terhadap istrinya untuk menegaskan reposisi kekuasaan dirinya di ranah domestik.

Pendemi bayangan di ranah privat/ranah domestik selanjutnya berjenis KBG/KBGS terkait ekonomi dan kesehatan berbentuk KDRT. Tercipta dari pembatasan aktivitas (lockdown) yang mengakibatkan orang kehilangan pekerjaan atau pemotongan gaji dan ketidakcukupan makanan bergizi bagi peningkatan daya tahan tubuh keluarga. Hal ini menimbulkan peningkatan ketegangan di antara anggota keluarga yang berujung KDRT terhadap sosok yang paling rentan, yaitu perempuan atau ibu, karena tidak dapat menjalankan peran gendernya sebagai penyedia makanan yang layak dan bergizi bagi keluarga. Bahkan perempuan atau ibu dipaksa ke luar rumah yang rentan ancaman kesehatan untuk mencari kekurangan dana atau kecukupan makanan bergizi yang diperlukan keluarganya (McLaren, OrcID, Nguyen, \& Mahamadachchi., 2020). Ketegangan dalam rumah tangga disebabkan hal ini dan disertai KDRT dan IPV banyak mengakibatkan perceraian.

Pandemi bayangan berikut dalam ranah privat berjenis KBG dan berbentuk KDRT maupun IPV terkait unsur pendidikan (sosial), kehamilan dini (kesehatan/fisikal), dan kemiskinan (ekonomi) ketika lockdown dan perintah untuk tetap dirumah (stay at home order) adalah pernikahan anak perempuan di bawah umur. Penutupan sekolah terkait Covid-19 memberi kesempatan untuk keluarga miskin dan termiskinkan oleh pandemi untuk menikahkan anak gadisnya yang belum cukup umur untuk membebaskan keluarga gadis dari tekanan ekonomi dengan prospek menerima mas kawin dan kelegaan karena memiliki lebih sedikit mulut untuk diberi makan. Menikahkan anak gadis yang berisiko hamil (berumur 13-17 tahun) pada masa lockdown dan stay at home untuk mengatasi kekhawatiran dan menghindari stigma sosial terkait kehamilan di luar nikah. Selain itu, pernikahan dini yang dipaksakan oleh orang tua terhadap anak perempuan yang 
tidak berpotensi pencari nafkah adalah untuk mengurangi beban ekonomi dan keuangan keluarga yang semakin berat di masa pandemi (Jones, dkk., 2020).

Pandemi bayangan lainnya di ranah publik berjenis KBG/KBGS terjadi di tempat umum atau fasilitas publik dalam bentuk KDRP dengan semua unsur kekerasannya ketika kebijakan protokol kesehatan diterapkan menyasar para perempuan yang tetap bekerja di masa pandemi. Perempuan yang berprofesi di bidang kesehatan di garis depan seperti tenaga medis, sukarelawan dan jasa pelayanan mengalami kerentanan dalam semua unsur kekerasannya (fisikal, psikis, seksual dan ekonomi) pada kondisi lockdown dan social distancing dari atasan atau rekan kerjanya dan orang asing. Perempuan pekerja yang menjadi korban pelecehan seksual sampai dengan pemerkosaan merasa malu, takut dan segan melaporkan kepada yang berwajib karena terancam akan kehilangan pekerjaan maupun penghasilan manakala lapangan pekerjaan lain sangat terbatas pada masa pandemi.

Pandemi bayangan berikut di ruang maya berjenis KBGS pada masa berlakunya lockdown dan WFH, telah mengubah orientasi kekerasan seksual fisikal komunitas ke kekerasan seksual online yang difasilitasi oleh teknologi internet. Perempuan sebagai bagian dari pengguna media sosial sangat rentan mengalami kekerasan seksual online dari hubungan pribadi, pacar, pertemanan, dan kerabat. Aksi body shaming, bullying. stalking, blackmailing, texting dilancarkan oleh pelaku kekerasan dengan mempergunakan aspek tubuh atau seksualitas perempuan korban tanpa persetujuannya.

The UN Women dalam situs jaringan internetnya memaparkan data bukti KTP di masa pandemi Covid-19 yang terjadi mulai pada saat lockdown diaktifkan pada Maret 2020 di hampir semua wilayah di seluruh dunia. Tingkat KTP dalam ragam bentuknya mengalami lonjakan peningkatan dari tingkat KTP pada masa sebelum pandemi. Peningkatan itu ditunjukkan dari jumlah korban yang selamat dan meninggal, jumlah panggilan darurat dan permintaan akan tempat penampungan bagi korban di beberapa negara yang tersebar di lima benua (Mlambo-Ngcuka, 2020).

Terdapat pula bukti peningkatan pernikahan dini anak perempuan di Ethiopia, Kenya, Malawi dan Nepal, kemudian di Asia Selatan, diikuti oleh Afrika Barat dan Tengah, dan terakhir, Amerika Latin dan Karibia (Jones, dkk., 2020) Ada peningkatan laporan serangan fisik maupun verbal terhadap petugas kesehatan di Cina, Italia dan Singapura. Menurut beberapa sumber di Inggris, Swedia, dan di tempat lainnya sudah ada 
peningkatan eksploitasi seksual online terhadap anak perempuan sejak lockdown Covid19 (International Federation of Red Cross and Red Cresent, 2020).

Tingkat sebenarnya dari KTP di tengah Covid-19 kemungkinan besar tidak akan pernah diketahui. Banyak penyebabnya antara lain insiden kekerasan tidak dilaporkan dan tertahan oleh penerapan kebijakan lockdown dan social distancing; sarana dan fasilitas dalam menangani aduan KTP tidak tersedia atau tidak memadai; personil yang berwenang terbatas dan terfokus pada pelayanan kesehatan pandemi. Lebih dari itu, terdapat kendala lain yang disebabkan oleh keraguan dan ketakutan dari pihak korban itu sendiri akan kepastian hukum yang adil mengenai KTP di negaranya. Korban sadar berada dalam posisi yang tidak menguntungkan secara gender dan seksualitas dalam stuktur kekuasaan maskulin yang timpang (hegemonic masculinity) yang berlaku secara universal dan berakar sejarah yang sangat panjang di banyak negara dan budaya di seluruh dunia.

Negara yang tidak dapat memenuhi kewajiban dan tanggung jawabnya sesuai implementasi Deklarasi Beijing untuk mengakhiri KTP, dan Deklarasi HAM untuk melindungi warga negaranya, pada masa berlangsungnya pandemi bayangan dari pandemi Covid-19, berarti negara menambah unsur KTP lainnya dengan negara sendiri sebagai pelaku kekerasan.

Dalam Volume 5 Nomor 2 pada bulan Mei 2021, Intermestic: Journal of International Studies terdapat satu artikel yang membahas tema yang serupa dengan esai editorial ini, yaitu mengenai gender dan seksualitas dalam hubungan internasional terkait pelecehan seksual. Artikel itu berada di nomor urut pertama berjudul "Gender Analysis of Sexual Misconduct in UN Peacekeeping Operations" yang ditulis oleh Rikianarsyi Arrassyidinta Naramanik Wirantoputri. Artikelnya mengeksplorasi faktor penyebab tetap terjadinya eksploitasi dan pelecehan seksual yang dilakukan oleh pasukan perdamaian Perserikatan Bangsa-bangsa (PBB) terhadap perempuan lokal di negara konflik. Hal yang dikaji dalam artikelnya adalah kebijakan PBB mengenai pelarangan beragam jenis relasi seksual pasukan perdamaian PBB dan perempuan lokal, data laporan tuduhan eksploitasi dan pelecehan seksual yang disampaikan penduduk, dan Indeks Perempuan, Perdamaian, dan Keamanan (WPS Index) dari negara pengirim dan penerima pasukan perdamaian PBB. Berdasarkan penelitiannya, artikel ini berargumen bahwa dalam penugasan misi perdamaian, terdapat aspek gender yang diabaikan oleh PBB, yakni budaya patriarkhi di 
kedua kelompok negara, pandangan/gagasan hipermaskulin dari pasukan militer, dan tujuan berdimensi gender dari negara pengirim yang ingin membentuk dan mempertontonkan identitas mereka sebagai pelindung.

Artikel-artikel berikutnya bertema ragam yang menarik untuk dibaca. Artikel kedua berjudul "Assessing Russia's Military Strategy in The Eastern Mediterranean Through the Establishment of an A2/AD (Anti-Access/Anti Denial)" ditulis oleh Militia Christi Pandelaki dan Anak Agung Banyu Perwita. Artikel ini mengenai strategi Rusia dalam melindungi kepentingan nasionalnya di Mediterania Timur dengan membentuk perluasan zona A2/AD (Anti-Access/Area Denial). Artikel ketiga "Barriers for Shanghai Cooperation Organization (SCO) To Pave Road to Supranationalism" ditulis oleh Mahbi Maulaya yang mempertanyakan kemampuan SCO meningkatkan kapabilitas dan kompetensinya sebagai organisasi regional dengan menjadi organisasi supranasional dan juga kemampuan SCO memasukkan norma dan nilai supranasionalisme ke dalam mekanismenya. "Kebijakan Keamanan Energi Tiongkok di Afrika Pada Periode Xi Jinping (2013-2019)" merupakan artikel keempat ditulis oleh Nur Ulfa Rosinawati dan Fahlesa Munabari yang menganalisis strategi Tiongkok dalam mengamankan kebutuhan minyaknya di Afrika di bawah pemerintahan Presiden Xi Jinping pada periode 20132019. Artikel selanjutnya adalah yang kelima "Whose Governance, Which Legitimacy? Myanmar's Collective Agency in A Domineering Framework on The Rohingya Crisis" ditulis oleh Kevin Ali Sesarianto. Artikelnya mengeksplorasi mengapa Myanmar menolak intervensi Perserikatan Bangsa-Bangsa (PBB) tetapi menerima intervensi Indonesia dalam membahas hal yang sama persis, yakni krisis Rohingya di tahun 2017. Artikel keenam yakni “Evaluating Indonesia's Disaster Diplomacy Practices Under The Jokowi Administration In 2018" ditulis oleh Surwandono, Zain Maulana, Tri Astuti Susanthi Retnoningsih dan Ariyanto Nugroho Artikel ini mengevaluasi praktik diplomasi bencana Indonesia tahun 2018 terkait bantuan internasional, yang di satu sisi diplomasi bencana dapat berperan dalam mengurangi risiko bencana. Di sisi lain, bantuan internasional dianggap sebagai faktor yang dapat menurunkan legitimasi pemerintah dalam menangani bencana. Artikel ke tujuh yaitu "Komitmen Indonesia Dalam Liberalisasi Jasa Telekomunikasi: GATS, AFAS, dan ASEAN+" ditulis oleh Safura Fitri Hanifah, Azhar, Nurul Aulia, dan Ferdiansyah. R, yang menganalisis hubungan antara rezim perdagangan dunia WTO dengan perjanjian perdagangan regional. Artikel 
kedelapan ditulis oleh Anggar Shandy yang berjudul "World Social Forum Sebagai Pengorganisasian Politik Multitude”. Artikel ini menganalisis model perlawanan serta tuntutan dan proposal World Social Forum (WSF). Dengan menggunakan konsep multitude dari Hardt dan Negri sebagai kerangka analisisnya. Artikel kesembilan, adalah "Merauke "Food Estate”:Alternatif Penanganan Konflik Di Papua Dalam Perspektif Ekonomi-Sosial dan Budaya" ditulis oleh Binsar Sianipar dan Amanah Nurish. Artikel ini menganalisa food estate di Merauke sebagai alternatif penanganan konflik di Papua dari perspektif ekonomi-sosial dan budaya. Artikel terakhir yaitu kesepuluh berjudul "Hyundai Investment on Electric Vehicles In Indonesia: A Push and Pull Factors Analysis. Di tulis oleh Achmad Ismail dan Darynaufal Mulyaman yang menganalisis alasan Hyundai memutuskan untuk membuat investasi langsung di Indonesia mengenai kendaraan listrik yang ditinjau melalui teori faktor pendorong dan penarik (the Push and Pull Factors)

Akhir kata, kami menghaturkan ucapan terima kasih tak terhingga atas kesediaan para mitra bestari dan para penulis dalam mewujudkan penerbitan e-Jurnal INTERMESTIC: Journal of International Studies Volume 5 Nomor 2 pada bulan Mei 2021 ini.

Hormat kami,

\section{Arry Bainus dan Junita Budi Rachman}

Pimpinan Editor dan Wakil Pimpinan Editor

\section{Referensi}

ASEAN. (n.d.). ASEAN Regional Plan of Action on the Elimination of Violence against Women (ASEAN RPA on EVAW). Nations, Association of South East Asian. Diakses pada Mei 2021, dari https://asean.org

CEDAW Committee. (1992). Diakses May 19, 2021, dari "General recommendation No. 19: Violence against women" (PDF).: https://tbinternet.ohchr.org/Treaties/CEDAW/Shared\%20Documents/1_Global/I NT_CEDAW_GEC_3731_E.pdf

Cresent, I. F. (2020, May 14). Relief Web. Diakses dari Relief Web: https://reliefweb.int/sites/reliefweb.int/files/resources/IFRC-SGBV-COVID-19Technical-Guidance-Note-FINAL_14May.pdf

Department of Health, R. o. (n.d.). https://doh.gov.ph/node/1414. Diakses dari https://doh.gov.ph/node/1414: https://doh.gov.ph/node/1414 
Jones, N., Gebeyehu, Y., Gezahegne, K., Iyasu, A., Workneh, F., \& Yadete., W. (2020, July). Child marriage risks in the context of covid-19 in Ethiopia. Gender Adoloscence Global Evidence.

Lombard, N., \& McMillan, L. (2013). Violence Against Women. Current Theory and Practice in Domestic Abuse, Sexual Violence and Exploitation. London: Jessica Kingsley Publishers.

McLaren, H. J., OrcID, K. R., Nguyen, K. N., \& Mahamadachchi., K. N. (2020). Covid19 and Women's Triple Burden: Vignettes dari Sri Lanka, Malaysia, Vietnam and Australia. Social Sciences, 9(5), 87. doi:doi.org/10.3390/socsci9050087

McMillan, L. (2007). Feminists organising against gendered violence. New York: PALGRAVE MACMILLAN.

Mlambo-Ngcuka, P. (2020, April 6). Violence against women and girls: the shadow pandemic. Diakses pada 19 Mei 2021, dari UNWOMEN: https://www.unwomen.org/en/news/stories/2020/4/statement-ed-phumzileviolence-against-women-during-pandemic

Sri, A. S., Das, P., Gnanapragasam, S., \& Persaud., A. (2021). COVID-19 and the violence against women and girls: 'The shadow pandemic'. International Journal of Social Psychiatry, 1(3). doi:DOI: 10.1177/0020764021995556

United Nations. (2020, July 3). Diakses pada 19 Mei 2021, dari https://www.un.org/press/en/2020/sgsm20160.doc.htm

WHO. (2005). WHO Multi-country Study on Women's Health and Domestic Violence Against Women. Geneve: WHO.

WHO. (n.d.). Violence Against Women, The Health Sector Responds. Diakses May 19, 2021,

dari https://www.who.int/violence_injury_prevention/publications/pvl_infographic.p df

Women, U. (2021, March). UN Women. Diakses dari UN Women Website: https://www.unwomen.org/en/what-we-do/ending-violence-againstwomen/facts-and-figures

Women, U. (n.d.). UN Women. Diakses dari UN Women Web Site: https://www.unwomen.org/en/what-we-do/ending-violence-against-women

Women, U. (n.d.). UN Women. Diakses dari UN Women Web Site: https://www.unwomen.org/en/what-we-do/ending-violence-againstwomen/global-norms-and-standards 